\title{
Implementation of Internal Academic Quality Audit in Higher Education
}

\author{
Dewi Nofrita $^{1}$, Unifah Rosyidi ${ }^{2}$, Neti Karnati ${ }^{3}$ \\ \{Dewinofrita_mp15s3@mahasiswa.unj.ac.id ${ }^{1}$, unifahr@gmail.com² ${ }^{2}$ netiyupan@yahoo.com ${ }^{3}$ \} \\ Universitas Negeri Jakarta, Indonesia ${ }^{1,2,3}$
}

\begin{abstract}
Quality is a measure of an organization's essential goal, and activity required to maintain its existence and development in accordance with the highly competitive global era. Currently, quality is an obligation and not an option in every Indonesian university. Hence, universities should develop a quality assurance system, aimed at carrying out internal controls by conducting academic quality audits. This research is intended to find out ways to implement internal academic audit (AMAI) in universities. Implementation of the interior quality guarantee was made using one of the highest education quality control management system in line with the national standard. This research made use of a descriptive qualitative approach. Data was collected through, interviews, observation, and documentation. Primary data were obtained by the Chancellor, and Auditor team, while the researchers made use of observation techniques, and documented studies to captured secondary data. Qualitative steps, which showed narrative text, and data reduction was used to analyze data. In conclusion, the study shows that the process used to implement the internal academic quality audits did not meet the required established standards. Hence, it is imperative to collaborate with various parties starting from the institute, faculty and study program level to participate in internal academic quality audit activities.
\end{abstract}

Keywords: Internal academic audit, Quality, Policy, Higher Education

\section{Introduction}

The level of progress associated with the civilization and development of science, and technology, can be attributed to human resources. These factors cannot be separated education because as its development remains an important requirement. Educational institutions play a vital role in producing human, technological and health resources. With the increase in the quest for proper education by communities, it has become imperative to improve the quality of higher education and its services. (Juha Kettunen, 2012[1]: Lia Dahlia, 2013[2])

The Government in a bid to improve the Gatra education implementation policy in the Education Sector gave birth to Law Number 20 of 2003 (Undang-Undang Nomor 20 Tahun 2003) education strategy on the national education system and Law Number 14 of 2005 (Undang-Undang Nomor 14 Tahun 2005) theory on Teachers and lecturers in Indonesia. The government issued a policy which resulted to the inception of the Higher Education Law number 12 of 2012 (Undang-undang Pendidikan Tinggi No12 Tahun 2012) guaranteeing the first level of quality assurance system in 51 states as follows: (1) higher education is capable of utilizing science and technology which is useful for society, nation, and state; and (2) The government system organizes higher education quality assurance to obtain quality education.[3] 
Article 52 states that: (1) higher education quality assurance is a systemic activity used to enhance the quality of education in a sustainable manner; (2) quality assurance is carried out through the establishment, implementation, control and improvement of academic standards; (3) a guarantee system for improved education standards in universities; and (4) the higher education quality assurance system in paragraph (3) is based on the university database.

According to article 53 the higher education quality assurance system referred to in article 51 paragraph states that(2): (1) an internal quality assurance system should be developed by universities; and (2) external quality assurance systems carried out through accreditation.

With regards to the improvement of the quality of education inputs, processes, and outputs as well as the development of academic quality assurance systems in universities, an academic quality audit is needed. The required academic review is poised to regulate all internal academic quality audit activities to fulfill the wishes of the community and government, in the implementation of quality tertiary institutions. The Ambon Islamic State Institute of Religion (IAIN) has established a unit of quality assurance institutions (LPM) in the IAIN Ambon statute. One of the government's policies in improving the quality of education in Indonesia is to create higher education institutions aimed at enhancing academic excellence to educate the nation's life. Higher education function is to organize education, research, and community service programs capable of providing all that is needed to produce graduate capable of meeting the standard of the consistently developing labor market.

The implementation of internal academic quality audit aims to improve the quality of Ambon IAIN, especially that of graduates, human resources, lecturers and employees, as well as its facilities and infrastructure. As a result of this, researchers are interested in examining the implementation of internal academic quality audits. In implementing the various education strategies, many challenges were faced, such as the quality of the required human resources, the completeness of infrastructure, input of students, parents, and the community. Out of a total of 20 staffs of the Ambon IAIN, only one professor and a doctorate holder were found. Meanwhile, academic demands require teaching staff to have academic and doctoral degree holders.

Education is said to be of high quality if the college involved can produce highly skilled graduates capable of competing with other college graduates, and experienced in their various chosen career paths. A tertiary institution with numerous human interests every academic year is considered quality; however, most of these institutions tend to have a poor or unprofessional registration process.[5]

The phenomenon above, if left unchecked, will have an impact on the quality of the institution as a whole and affect its academic goals. This problem indicates that the internal quality audit and follow-up that should have been carried out still have some weaknesses.

\section{Research methods}

A qualitative approach is used to analyze the implementation of internal academic quality audits at the Ambon State Islamic Institute. In this study, descriptive data were produced which aimed at providing a detailed description of the implementation of internal academic quality audits at the Ambon Islamic Institute of Religion.

Data were collected through interviews, observation, and documentation. The primary data sources are:/ (1) Chancellor, Vice Chancellor I, Vice Chancellor II, Vice Chancellor III, Lecturers, Administration. (2) Auditor team. In collecting secondary data, researchers used observation techniques, and previously documented information on the studies. 
To start each qualitative study, three essential things must be met: (1) what are you going to study, (2) how are you going to collect the data (source of receiving data), and (3) the source of data.[6]

In qualitative research, the researcher should be able to determine if the study is a narrative or a description and adequately explained both oral and written. The behavior of the subjects observed in the field is also part of the data in this study.[7] The data analysis technique used is descriptive narrative. This technique according to Miles and Huberman is applied using three methods, namely (1) Data reduction; (2) Presentation of data, and; (3) Concluding.[8] the research data set can be seen at https://osf.io/dashboard. The analysis steps are shown in the following figure:

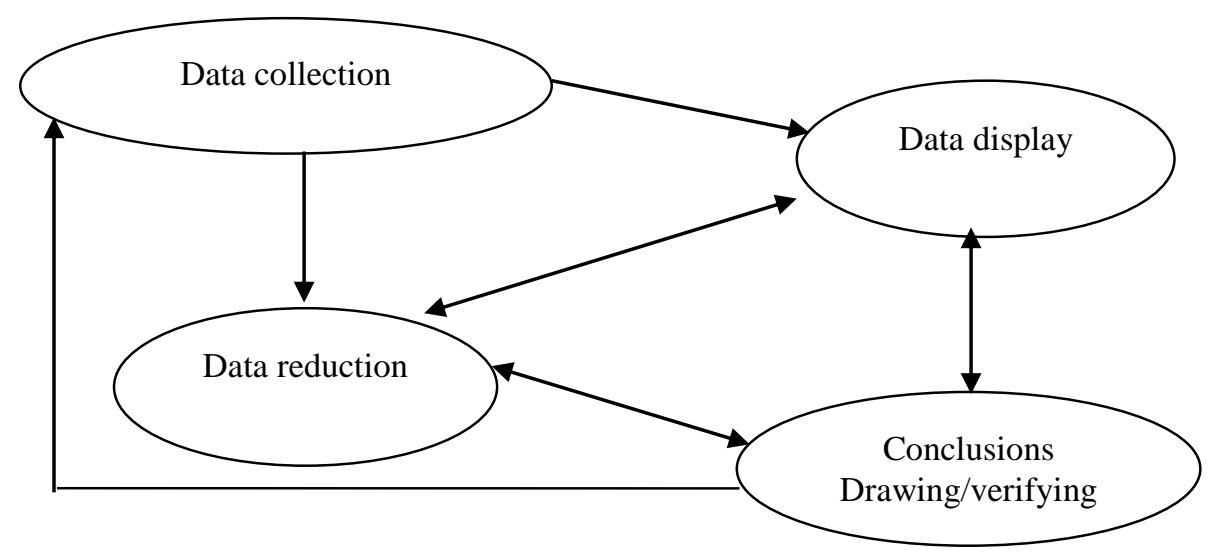

Fig 1: analysis data (interactive model)

\section{Result and Discussion}

\subsection{Understanding Quality}

According to Juran (1988), "quality is Fitness for Use (readiness to work), “ Crosby (1979) describes it as something right when needed; while Ton Vroinjenstijn (2002) states that quality is an underlying condition for competency, with the ability to survive. With regards to education, quality is defined as the goals and skills of graduates which is determined by the educational institution in carrying out strategic plans in order to meet a set standard (Muh. Fitrah, 2018[9];

Higher academic excellence should be able to provide outstanding educational satisfaction to the community, capable of competing with other college graduates, and professionally ready to work. But on the contrary, communities tend to analyze the quantity of a tertiary institution by the number of people interested in gaining admission into it every year.

\subsection{Definition of Internal Academic Quality Audit}


Quality audit is a systematic, independent and documented process for auditing and evaluating objectives to determine the best audit that has been fulfilled. (Education National Standards: 2001). It is also used to determine the level and effectiveness of implemented management standards that have already been set and manually written.(Erwin Dwi Edi Wibowo, 2014[10]; Novi Yanti, 2013[11])

The objectives of an internal academic quality audit are:/ (1) Researching and guaranteeing educational formalities on academic policies, standards, regulations, and IAIN Ambon learning manuals. (2) Examining the commercial direction and implementation of academic, and IAIN Ambon procedures such as quality of audit based on the product /service, (b) Quality of Process Audit based on performance, and (c) System Quality Audit based on the system.

\subsection{Implementation of Internal Academic Quality Audit}

The implementation of internal academic quality audit consists of (a) various data collection methods based on the observed implemented activities, request to interview the auditee, demonstration by the auditee, review of documents, checklist, search evidence, cross-checking information from outside sources, analyzing data and information, drawing conclusions, and providing recommendations.

To be able to collect data well, it is necessary to compile the required instruments. Internal audit /monitoring and evaluation policies depend on Higher Education policies. Internal audit /monitoring teams are determined based on the institutional procedures listed in the Quality Policy document which should be included in the academic calendar two weeks earlier.

The approach of quality assurance means that the process is mutual inter-related, and integrated to make a whole. The implementation of the academic quality assurance at IAIN Ambon is detailed in the Quality Manual. 1) The details of activities carried out in AMAI opening meeting are: a) Introducing the audit team members to their leader, b) Reviewing the scope and objectives of the audit, c) Delivering methods and procedures used to carry out the audit, d) Affirming formal relationship between the audit and the audit team, e) Confirmation of available necessary resources, f) Confirm the schedule of meetings and closing audits, g) Clarifying that the audit plan is not clean. 2) Its field inspection includes a) Collection of evidence through interviews, document checking, observation of activities and site conditions. If there are indications that lead to the recording of nonconformities, even if they are not included in the checklist and further investigated, the results of the interview must be tested by seeking information about the same from other independent sources. b) Observation of audits is documented after which the team reviews all obtained observations to determine if there is a discrepancy that must be reported. Research findings in the implementation of internal academic quality audits include: Limitations in formulating quality documents, Lack of commitment from university stakeholders, Limited number of human resources in quality assurance units / institutions, Limited number of human resources in work units / study programs, busy or routine activities, and documentation of activities that are not well organized, as well as unpreparedness of facilities and infrastructure in the field of information technology. 


\section{Conclusion}

Based on the results of this study, it can be concluded that the implementation of internal academic quality audits is following established standards. Institutions and study programs, currently participate in good internal quality audit activities making the documentation system complete and structured to support the internal quality assurance system. The audit results explain the problems, findings, suggestions, and recommendations. Also, there is a follow-up by the auditor to monitor and ensure that the university takes the right actions.

Furthermore, the auditor team always participates in training or up-to-date information on quality assurance, and control groups in study programs. Universities programs are always based on the results obtained from monitoring, evaluation, and cultivating quality assurance.

\section{References}

[1] Creswell, J.W, Educational Research: Planning, Conducting, and Evaluating Quantitativ and Qualitative Research, Apper saddie River, N.J: Pearson Merill Prentice Hall (2008)

[2] Mohammad faisal amir.: Manajemen Kinerja Perguruan Tinggi, Jakarta: Mitra wacana media (2016)

[3] Miles \& Huberman, Analysis Data Kualitatif. Jakarta: UI Press (1984)

[4] Robert K. Yin, Qualitative Research from Start to Finish, New York: a division of Quilford Publications, Inc. (2011)

[5] Sudawan denim, Otonomi Manajemen Sekolah, Bandung: Alfabeta (2010)

[6] Peraturan Pemerintah Republik Indonesia Nomor 19 Tahun 2005 Standar Nasional Penddikan, Bab XV Pasal 91, ayat 1,2 dan 3, (2005)

[7] Peraturan pemerintahan Republik Indonesia Nomor 17 Tahun 2010 Tentang Pengelolaan dan Penyelenggaraan Pendidikan, Bab II, pasal 13, ayat 1 (2010)

[8] Juha Kettunen.: External and internal quality audit in higher education, The TQM Journal, Vol. 24. Iss: 6 (2012)

[9] Lia Dahlia.: Efektivitas Internal audit dan pelaksanaan good university governance pada perguruan tinggi, Junal ilmiah manajemen dan akuntansi Fakultas Ekonomi (IMAFE), 2013

[10] Erwin Dwi Edi Wibowo, Kebijakan mutu akademik Pendidikan Tinggi, Jurusan Administrasi Niaga FISIP Universitas Pandanaran, 2014

[11] Novi Yanti.: Sistem Informasi Audit Mutu Internal UIN Sultan Kasim Riau( Studi Kasus : Lembaga Penjaminan Mutu), Sosial Budaya: Vol 10 N0 02 Juli-Desember 2013, 2013

[12] Muh. Fitrah, Urgensi Sistem Penjaminan Mutu Internal Terhadap Peningkatan Mutu Perguruan Tinggi, Jurnal penjaminan mutu LPM Institut Hindu Dharma Negeri Denpasar, Volume 4 Nomor 1 februari 2018, 2018 